\title{
The EPISTEMic InJUSTICE EXPRESSED IN "NORMALIZING" SURGERY ON CHILDREN WITH INTERSEX TRAITS ${ }^{1}$
}

\author{
- Renata Ziemińska -
}

\begin{abstract}
I present the notion of epistemic injustice coined by Miranda Fricker and apply it to the situation of people with intersex traits, especially intersex children who are the subjects of "normalizing" surgery. Several studies from Polish hospitals show that both early "normalizing" surgery and the decision to postpone such surgery can result in harm to an intersex child. For this reason, I claim that "normalizing" surgery is only an expression of the epistemic hermeneutical injustice existing before the surgery and that its source is the lack of an empirically adequate notion of sex characteristics. The binary notion is too simple to grasp intersex traits, and this epistemic dysfunction turns into practical harm. In contrast to Morgan Carpenter, I defend the nonbinary gender category as being important to limiting "normalizing" surgery.
\end{abstract}

Keywords: Miranda Fricker, epistemic injustice, children with intersex traits, early "normalizing" surgery, binary notion of two sexes

Published online: 9 June 2020

\section{Epistemic injustice according to Miranda Fricker}

Miranda Fricker (2009) seems to follow Socrates when she claims that evil can come from a kind of epistemic dysfunction. She coined the term epistemic injustice to describe the phenomenon of epistemic dysfunction that turns into moral dysfunction or, in terms of virtue epistemology and ethics, the epistemic vice that turns into a moral vice. It is a situation when "someone is ingenuously downgraded and/or disadvantaged in respect of their status as an epistemic subject" ${ }^{\prime 2}$ and at risk of also being negatively treated nonepistemically.

There are at least two forms of epistemic injustice: testimonial and hermeneutical: "Testimonial injustice occurs when prejudice causes a hearer to give a deflated level of credibility to a speaker's word; hermeneutical injustice occurs at a prior stage, when a

\footnotetext{
Renata Ziemińska

Department of Philosophy and Cognitive Science

University of Szczecin

Krakowska 71, 71-017 Szczecin, Poland

e-mail: renata.zieminska@usz.edu.pl

${ }^{1}$ This work was supported by the National Science Center, Poland [grant number 2014/15/B/ HS1/03672].

${ }^{2}$ Fricker (2017): 53.
} 
gap in collective interpretative resources puts someone at an unfair disadvantage when it comes to making sense of their social experience." ${ }^{3}$

Testimonial injustice can be illustrated by the old prejudice that women are unable to reason and are too emotional. In such a prejudiced social context, a female voice has a deflated level of credibility, for instance, in male-dominated corporation management teams. ${ }^{4}$ The epistemic result is that some ideas are too quickly rejected, and the free circulation of ideas is blocked. The moral result is that women are degraded as knowers and as humans. This can be followed by many other secondary disadvantages.

Hermeneutical injustice as a harmful gap in collective interpretative resources is illustrated by the story of Carmita Woods, who worked as a lab assistant at a university department of nuclear physics. She was the object of unwanted molestation by a distinguished professor (for instance, "he cornered her in the elevator and planted some unwanted kisses on her mouth" ${ }^{\prime \prime}$ ). Woods ceased to use the elevator, developed back and neck pains and, after being denied a transfer to another department, quit her job. She applied for unemployment insurance but was ashamed to describe the reason ("she had no namable reason to cite" ${ }^{\prime \prime}$ ), and as a result, she was denied the unemployment benefits. Feminist lawyers tried to help her, coining the term sexual harassment. ${ }^{7}$

Before the term was coined, it was difficult to distinguish molestation and flirting, and it was difficult to understand that such molestation is a harm. Many molested women like Carmita Woods suffered but were unable to cope with their situation because there was no term in the social vocabulary for such a phenomenon (it was a lacuna in social hermeneutical resources). The reason for this lack of terminology was that women, the most frequent victims of sexual harassment, have, in the past, had limited participation in the processes of creating social vocabulary. Female voices were strengthened during the second wave of feminism in Western culture, and a better understanding of the female experience was developed. The term sexual harassment was coined at that time. ${ }^{8}$

Both forms of epistemic injustice are linked to some kind of inequality of power. In contrast to testimonial injustice, hermeneutical injustice is a structural notion, and no agent perpetuates the injustice (even unintentionally). It is a structural vice of the social imagination. Testimonial injustice is the exclusion of a speaker, and hermeneutical injustice is the exclusion of "what they are trying to say". ${ }^{9}$ Regular users of public language transmit the lacuna and materialize the harm. Only the virtuous and the most sensitive users can mitigate the harm. According to Fricker, regular users are partly justified in their hermeneutical dysfunction. The professor was probably unaware of how harmful his behavior towards Carmita Woods was to her. He was cognitively dysfunctional due to the lacuna in the social imagination and conceptual resources. Typical epistemic injustices are nondeliberate and unintentional. It was also difficult for Carmita Woods

\footnotetext{
Fricker (2009): 1

${ }^{4}$ Ibidem: 47.

${ }^{5}$ Ibidem: 150.

6 Ibidem: 162.

7 Ibidem: 150.

8 Ibidem: 152.

9 Ibidem: 162.
} 
to understand her own experience of harassment. This can explain why she was unable to protest and stop the mistreatment. ${ }^{10}$

Fricker also gives the example of gay people living in a culture that interprets their sexuality as a sin or disorder. This interpretation is dissonant with gay people's experience of simple love for a same-sex person, and public vocabulary has a lacuna regarding this experience. Therefore, the experience is inarticulable in the vernacular, and members of society, including gay people themselves, do not understand this experience. They interiorize the public interpretation and suffer for both external and internal reasons (they fear the term, want their nascent identity to be disguised, finding it shameful). This hermeneutical injustice (the lack of representation of an experience) may be damaging to the development of the self. According to Fricker, this lacuna can be filled by allowing the relevant group to participate in the process of creating social meaning. ${ }^{11}$ Of course, hermeneutical injustice may be followed by testimonial injustice. A member of a marginalized group can be doubly wronged as a speaker by the lacuna in conceptual resources and by a deficit of credibility. ${ }^{12}$

Fricker's concept of epistemic injustice can be applied to another minority group: people with intersex traits, who do not fall into the binary male/female divide. I claim that the concept is crucial in explaining the harm of performing "normalizing" surgery on children with intersex traits. Morgan Carpenter writes that people with intersex traits face testimonial injustice: "the credibility of intersex voices is diminished, even where they speak about personal lived experience".${ }^{13}$ He also writes about hermeneutical injustice: people with intersex traits are "unable to make sense of their experience due to prevailing social norms" ${ }^{14}$ I claim that the specific form of epistemic injustice faced by people with intersex traits is hermeneutical injustice. It is not only a problem that intersex voices have a deflated level of credibility, but it is also a structural problem that is easy to miss: their voices cannot be understood in the public arena, as the public binary notion of two sexes makes too little space for these voices. The intersex experience is closed behind hospital doors.

\section{People with intersex traits}

People with intersex traits are born with some sex characteristics (genital, gonadal, chromosomal) that are both male and female or neither male nor female, for instance, a vagina and testes or gonads with both ovarian and testicular tissue. As they have sex characteristics that are not clearly male or female, they are excluded from the simple male/female binary divide. Intersex people want others to know that "sex is a spectrum and that people with variations of sex characteristics other than male and female do exist" ${ }^{15}$ In medical language, intersex conditions are referred to as DSDs (disorders of sex

\footnotetext{
10 Ibidem: 151.

${ }^{11}$ Ibidem: 162.

${ }^{12}$ Ibidem: 159.

${ }^{13}$ Carpenter (2018): 459 .

${ }^{14}$ Ibidem: 467.

${ }^{15}$ Ghattas (2015): 9.
} 
development). Some types of DSDs include CAH (congenital adrenal hyperplasia), CAIS (complete androgen insensitivity syndrome), PAIS (partial androgen insensitivity syndrome), 5-AR (5-alpha reductase deficiency), and variations in sex chromosomes (neither $46, X X$ nor $46, X Y) .{ }^{16}$ Intersex genitals occur in 1 in 4500 newborns, ${ }^{17}$ while other cases are diagnosed in puberty or later in life; after including hypospadias ${ }^{18}$ and chromosome variations, the prevalence of DSDs is approximately $0,5 \%$ in the general population. ${ }^{19}$ In Poland, it is estimated to be $0,24 \%{ }^{20}$

Let me illustrate this with an example of a sports celebrity, Maria Patino, a Spanish hurdler who was disqualified from female sports competitions in 1985 after a chromosomal test. Medical examination revealed that her karyotype was male, 46,XY, and she had undescended testes in her body. The data are public, as Patino published her medical records to fight for a license to run again (which she achieved in 1988) and to help other sportswomen with genetic variances. Her medical diagnosis is CAIS: the body does not respond to testosterone that is produced by testes. In such cases, during prenatal life, sex development goes in a female direction, and later gender identity is almost always female. She wrote, "I could hardly pretend to be a man; I have breasts and a vagina." ${ }^{21}$ She was disqualified as a woman, and she was also not a man; her sex characteristics challenge the binary male/female divide.

At present, there is much medical data on newborns with intersex traits ${ }^{22}$ and considerable social data about the life and psychological condition of intersex adults. ${ }^{23}$ Additionally, historians have described people with intersex traits in the past. ${ }^{24}$ We can find remarks about them in the Bible (there are some eunuchs, which were so born from their mother's womb; Matthew 19.12) and in Greek mythology (the story of how Hermaphroditus and the nymph Salmacis were united into one body with both breasts and penis; Ovid, Metamorphoses 4.285).

Therefore, there is much data to challenge the binary division of people into two exclusive groups: men and women. ${ }^{25}$ However, the division has been preserved by interpreting intersex traits as a congenital disorder. Similarly, newborns with six fingers or six toes are ignored by anatomical patterns, and their rare trait is interpreted as a disorder. Biology "is thinking in terms of populations instead of type specimens" ${ }^{26}$ That is why biological theories treat intersex organisms as "anomalies". They are statistically rare and, in this sense, "anomalous", but such a name and position entail a negative value judgment. The same holds true for the term disorder. Scholars have pointed to the stigma

${ }^{16}$ Hughes, Houk, Ahmed et al. (2006); Lee, Nordenström, Houk et al. (2016). The complete list is longer, and it is disputable whether some of the conditions included are actually DSD.

17 Hughes, Houk, Ahmed et al. (2006): 554.

${ }^{18}$ It is a condition where the urethral opening is on the underside of the penis. See Carmack, Notini, Earp et al. (2015): 1 .

${ }^{19}$ Lee, Nordenström, Houk et al. (2016): 159.

${ }^{20}$ Pisarska-Krawczyk, Jarząbek-Bielecka, Mizgier et al. (2014): 265.

${ }^{21}$ Patino (2005): 538.

${ }^{22}$ Kolesinska, Ahmed, Niedziela et al. (2014); Lee, Nordenström, Houk et al. (2016).

${ }^{23}$ Davis (2015); Schweizer, Brunner, Handford et al. (2014).

${ }^{24}$ Boczkowski (1966); Reis (2009); Mak (2012).

${ }^{25}$ Ziemińska (2018): 123.

${ }^{26}$ Koertege (2004): 872. 
accompanying the use of the word disorder and proposed intersex conditions, variations in sex development, differences in sex development or diverse sex development. ${ }^{27}$ The term disorders of sex development has been rejected by the largest international organization of intersex persons. ${ }^{28}$ Most intersex people can live as they were born without threats to their life or the dysfunction of their organism, and they are classified as people with a disorder just because their anatomy is different.

It is important to remark that it is possible to treat such rare anatomy as equally valuable, healthy, and natural variances or even to celebrate it as a special gift. ${ }^{29}$ For the time being, the "disorder strategy" is comfortable to the dominant majority in society. However, such interpretation of intersex bodies has harmful consequences, and it often leads to "normalizing" surgery.

\section{Performing "normalizing" surgeries on children with intersex traits}

Performing "normalizing" surgeries on intersex children is intended to help such individuals conform body to social binary norms and to avoid the "stigma" of having both female and male sex characteristics or neither female nor male ones. Sometimes, there is a medical necessity for surgery on intersex children, for instance, to allow urogenital functions or to remove streak gonads with a high risk of cancer. However, testes in girls are often removed before puberty even if there is no medical necessity to do so but just to prevent the masculinization of their appearance. ${ }^{30}$ Similarly, many surgeries on intersex genitals are not medically necessary ${ }^{31}$ but are intended to achieve a male or female appearance.

In the middle of the $20^{\text {th }}$ century, a team of researchers from Johns Hopkins University, USA, which included psychologist John Money, elaborated treatment protocols for early surgery on the assumption that the gender identity ${ }^{32}$ of newborns is neutral and parents can steer its development in accordance with surgically assigned sex. ${ }^{33}$ This assumption was criticized inside medical circles as too simple. ${ }^{34}$ The public falsification of this assumption was a BBC documentary titled The Boy Who Was Turned into a Girl, based on John Colapinto's book. ${ }^{35}$ In this story, a baby boy has his penis accidentally destroyed during a routine circumcision, and the decision was made to raise the child as a girl (testes were removed, the rest of the genitals were reshaped into vulva). Aro-

\footnotetext{
${ }_{27}$ Reis (2007); Diamond (2009); Johnson (2017).

${ }^{28}$ Ghattas (2015); Viloria (2017); Carpenter (2018).

${ }^{29}$ Davis (2015): 144.

${ }^{30}$ Lee, Nordenström, Houk et al. (2016): 173-4; Petriczko, Marcinkiewicz, Słowikowska-Hilczer et al. (2014).

31 "An intervention to alter a bodily state is medically necessary when (1) the bodily state poses a serious, time-sensitive threat to the person's well-being, typically due to a functional impairment in an associated somatic process, and (2) the intervention, as performed without delay, is the least harmful feasible means of changing the bodily state to one that alleviates the threat." Brussels Collaboration (2019): 18; see Earp (2019).

32 "An internally-felt sense of one's own relationship to social norms of gender" - Barnes (2019): 12.

${ }^{33}$ Zillén, Garland, Slokenberga et al. (2017): 41.

${ }^{34}$ Diamond, Sigmundson (1997); Davis (2015): 60.

${ }^{35}$ Colapinto (2000); Harper (2007): 43.
} 
und puberty, the child expressed a male gender identity and rejected the gender of his rearing. ${ }^{36}$ This was not the story of an intersex baby, but it shows the power of prenatal hormones as a source of gender identity. This story captured media attention and helped intersex activists from the Intersex Society of North America, ${ }^{37}$ supported by feminist scholars such as Ann Fausto-Sterling and Suzanne Kessler, ${ }^{38}$ question medical treatment protocols. The Chicago Consensus Statement ${ }^{39}$ in 2006 was a kind of compromise between the medical community and the intersex community.

There are many studies on pre-Chicago Consensus treatment, but let me illustrate the situation by referring to a follow-up study among intersex patients at the Children's Memorial Health Institute in Warsaw, Poland. The results of the study are very similar to those presented in international studies. ${ }^{40}$ The Warsaw study was conducted around the time of the Chicago Consensus Statement, but the participants were treated according to pre-Chicago Consensus procedures. The participants were 19 persons with mixed (MGD) or partial gonadal dysgenesis (PGD) aged 17-26 years; 9 were raised as girls, and 10 were raised as boys. Participants with PGD had 46,XY chromosomes and bilateral ovotestes with partly testicular and partly ovarian tissue; participants with MGD had mosaic chromosomes 45,X/46,XY, one gonad streak, and one ovotestis. All had genitals ranging from a hypospadial penis to female genitals with some degree of masculinization. The criterion used to decide the sex assignment was the degree of external masculinization. ${ }^{41}$

In patients raised as girls, streak gonads and testicular tissue from mixed gonads were removed, and vaginoplasty was performed (between 1-9,5 years). Therefore, some of the girls had early vaginoplasty that required dilation that, as we know from other studies, "has caused severe psychological trauma to many children." ${ }^{42}$ In the patients raised as boys, streak gonads were removed, and the hypospadial penis was reconstructed. Seven males with hypospadias were the most successful group in the study.$^{43}$ None of the males had problems with gender identity. The quality of life of the female participants was much poorer. Two of them did not identify with the female gender but did not want reassignment and avoided intimate relations. None of the women had any sexual experience. "They expressed a limited interest in sex because of lack of sexual drive. None reported a bisexual or homosexual sexual orientation. None of the women had had sexual intercourse." ${ }^{44}$ Many of the women experienced an inferiority complex or neurotic behavior.

The authors of the study claim that the reason for the poor result for the women was an incorrect gender assignment and say that "the degree of masculinization of the

\footnotetext{
${ }^{36}$ Harper (2007): 43.

${ }^{37}$ Chase (2002).

${ }^{38}$ Davis (2015): 39, 56.

${ }^{39}$ Hughes, Houk, Ahmed et al. (2006).

${ }^{40}$ Ibidem.

${ }^{41}$ Szarras-Czapnik, Lew-Starowicz, Zucker (2007): 334.

${ }^{42}$ Zillén, Garland, Slokenberga et al. (2017): 45.

${ }^{43}$ Recently, early intervention for hypospadias has been criticized for the surgical complications that may follow: "There are no compelling reasons to justify performing medically unnecessary hypospadias surgery on individuals prior to an age of meaningful consent" - Carmack, Notini, Earp et al. (2016): 10 .

${ }^{44}$ Szarras-Czapnik, Lew-Starowicz, Zucker (2007): 336.
} 
external genitals is a poor prognostic value for later psychosexual traits" ${ }_{;}{ }^{4}$ according to the authors, the more important factor may be exposure to prenatal androgens. ${ }^{46}$ Some of the women had feminizing surgery before they could say whether they identified as female. On the grounds of this study, the authors question the assumption that "it is safest to choose the female sex for rearing a child born with genital ambiguity." 47

Indeed, as a result of changes after the Chicago Consensus Statement in 2006, the number of female assignments was reduced, ${ }^{48}$ and doctors started to carefully predict the most likely future gender identity of each particular child. This was progress, but no consensus was reached to ban early "normalizing" surgery entirely. ${ }^{49}$ There are some new cases showing that early surgery inconsistently corresponds with later gender identity. ${ }^{50}$ The gender identity of children with intersex traits cannot be predicted with accuracy (gender dysphoria affects between $8.5-20 \%$ of individuals with DSDs ${ }^{51}$ ), so waiting for their voice about their identity seems like a minimal requirement. ${ }^{52}$

Additionally, even if a sex assignment is accepted, there are other unsatisfactory results of early "normalizing" surgery. ${ }^{53}$ The report adopted by the Committee on Bioethics of the Council of Europe lists the following undesirable results: "genital dysfunction, scarring, loss of sexual feeling, loss of fertility, [and] chronic pain." ${ }^{54}$ Because of this risk, it is better to wait until the child is able to give informed consent. ${ }^{55}$

There are many ethical arguments for why "normalizing" surgeries should be delayed when they are not medically necessary and can be delayed. ${ }^{56}$ There is an argument for the child's right to bodily integrity, ${ }^{57}$ the child's right to an open future ${ }^{58}$ and

${ }^{45}$ Ibidem: 337.

${ }^{46}$ Ibidem: 334; on problems and methods of predicting future gender identity, see Lee, Nordenström, Houk et al. (2016): 168 .

47 Ibidem.

${ }^{48}$ Kolesinska, Ahmed, Niedziela et al. (2014).

${ }^{49}$ Lee, Nordenström, Houk et al. (2016): 176.

${ }^{50}$ In 2013 the Crawfords, the adoptive parents of an intersex child, sued the state of South Carolina and the Medical University of South Carolina for medically unnecessary genital removal surgery performed on their adopted intersex child. Their child identifies as a boy, but he was surgically corrected to being a girl at 16 months old. He was in state custody at the time of surgery, so it happened before the adoption. The adoptive parents claim that doctors had no medical reason to do the surgery so early and that they did not do what was the best interest of the child. See Davis (2015): 153. The process finished in 2017 with a settlement and high reparation paid to their intersex child mostly by the Medical University of South Carolina, https:/ / www.documentcloud.org/documents/3901419-Final-Settlement.html [Accessed 20.08.2017].

${ }^{51}$ Furtado, Moraes, Lago et al. (2012): 620.

${ }^{52}$ Earp (2019).

${ }^{53}$ Karkazis (2008); Feder (2014); Monro, Crocetti, Yeadon-Lee et al. (2017): 16.

${ }^{54}$ Zillén, Garland, Slokenberga et al. (2017): 40; Davis (2015): 90; Karkazis (2008): 27.

55 That is why the Organization Intersex International and other intersex social movement organizations like Inter/Act fight to ban early "normalizing" surgeries (Ghattas (2015); https:/ /oiieurope.org/ portugal-adopts-law-protecting-intersex-people/). On the one hand, female genital cutting is called a "barbaric abuse of human rights" (Chase (2002): 206), but on the other hand, "normalizing" surgeries on children are accepted by the law (Brussels Collaboration (2019): 20). We should either tolerate culturally motivated female genital cutting or not tolerate "normalizing" surgeries (Earp, Steinfeld (2018): 12).

${ }^{56}$ Earp (2019): 7.

57 Ibidem: 5.

${ }^{58}$ Darby (2013); Kubicius, Michałowska (2020). 
the child's right to genital autonomy. ${ }^{59}$ What is important for the parents (an appearance securing social acceptance) may not be so important for an adult with intersex traits suffering from chronic pain or nerve damage to sensitive tissue. An elderly child can say what their gender identity is and will be able to take part in the decision process or give informed consent. ${ }^{60}$

Despite recommendations and moral arguments against early "normalizing" surgery, such procedures continue to occur. ${ }^{61}$ This raises the question of why parents make such a decision concerning their own children and why doctors recommend it.

\section{Two cases from Poland of postponing surgery}

I would like to refer to two recent case studies of intersex girls from Polish hospitals after the Chicago Consensus statement.

(Girl 1): An eleven-year-old girl with an enlarged clitoris, partly fussed labia, $46, \mathrm{XY}$ karyotype, undescended testes in inguinal canals, high level of testosterone, and female gender identity was referred to a hospital and diagnosed with partial androgen insensitivity syndrome (PAIS). As she had a female gender identity, the decision was made to remove the testes to stop body masculinization in puberty and to supplement with estrogen to continue female puberty. The possible surgical alteration of the external genitalia was postponed until after puberty in accordance with Chicago Consensus recommendations (vaginoplasty before puberty has complication risks) to allow the owner of the body to take part in the decision (the patient was not interested in vaginoplasty). ${ }^{62}$ The authors of the case study add that after the removal of the testes, the girl lost a natural source of hormones. They do not mention, however, that the removal of the two gonads was also the end of her fertility; intersex cases are often presented as an emergency "that allows [practitioners] to abandon medical ethics." 63

(Girl 2): A baby was born with an enlarged clitoris, short vagina, no uterus, two undescended testes, and karyotype 46,XY. The baby was diagnosed with partial androgen insensitivity syndrome, and a female sex was assigned. When the child was four, a female identity was expressed, and one smaller abdominal testicle was removed. The second testicle in the inguinal canal was left, and the sex organs were not surgically corrected, as $11 \%$ of such children change their gender identity in puberty. When the girl was thirteen, the clitoris was significantly enlarged, and she grew male-type hair, but her identity was female. When the girl was nineteen, her body looked masculine (strong, dark body hair and facial hair, no breasts), and she was severely depressed. Bajszczak et al. reported that after the second gonad was removed, the external genitalia were surgically altered, and estrogen and antiandrogen therapy was applied (to develop breasts and eliminate body hair) some psychological improvement was achieved. ${ }^{64}$

\footnotetext{
${ }^{59}$ Earp, Steinfeld (2018): 8.

${ }^{60}$ Carmack, Notini, Earp et al. (2015).

${ }^{61}$ Council of Europe (2017): 9; Creighton, Michala, Mushtaq et al. (2014): 38; Monro, Crocetti, Yeadon-Lee et al. (2017): 11; Carpenter (2018): 472.

62 Petriczko, Marcinkiewicz, Słowikowska-Hilczer et al. (2014): 63.

${ }^{63}$ Davis (2015): 23.

${ }^{64}$ Bajszczak, Szarras-Czapnik, Oszukowska et al. (2013): 72.
} 
The first case shows a successful (as far as we know) post-Chicago Consensus treatment with partly postponed surgery. The second case shows the psychological trauma that resulted from postponing surgery. The story of Girl 2 shows that the life of some persons with intersex traits is difficult without surgery. "The struggles associated with intersex do not derive exclusively from the scalpel;" ${ }^{65}$ they derive from the simple binary notion of two sexes and the pathologizing of bodies that do not fit the binary.

Girl 2 was not harmed by physical pain, her fertility and sexual sensitivity were preserved, and an open option for future decisions remained. However, the girl was left with psychosocial trauma (without appropriate psychological support monitoring her distress). The reasons for her suffering are different from those of the nine girls treated according to the pre-Chicago Consensus procedure. Girl 2 can blame her parents and doctors for leaving her without professional support when the social environment was hostile to diverse sex characteristics. The pre-Chicago Consensus girls have their bodies irreversibly changed without waiting for their voices and informed consent. Girl 1 had a successful postponement (two testes were removed, genitals were left alone) as far as we know, but Girl 2 had a traumatic postponement (only one testis was removed).

The parents of intersex children face a tragic decision. Early "normalizing surgery" carries the risk of physical harm, but postponing such surgery risks social stigma and psychological trauma (when there is no appropriate support, or the child is not resilient against the stigma ${ }^{66}$ ). Doctors hold DSD team meetings to make decisions about a particular child. ${ }^{67}$ They make a recommendation, and the parents can accept it or not. Parents often blame themselves both for physical harm after surgery and for psychological pain in the case of refusing to consent to surgery. ${ }^{68}$ Georgian Davis writes that doctors "make treatment recommendations from the position of power and authority over the intersex 'emergency' they create. This leaves parents inclined to accept medical recommendations and simultaneously allows providers to evade responsibility for their actions." 69 Davis seems to defend parents and blame doctors. In my view, doctors only perpetuate the emergency that already exists in the social imagination. Doctors are also prisoners of the social imagination that is created by the whole society. It is not easy to stop early "normalizing" surgery when social exclusion and psychological trauma are at risk.

\section{The binary notion of two sexes as a source of epistemic injustice}

It seems obvious that the source of the trauma and the push for "normalizing" surgery is social pressure to fit into a narrow pattern of two sexes that I call the binary notion: "The aim of such cutting is typically to conform the child's genitals to a narrowly conceived gender binary." 70 The simple, binary female/male divide is a kind of epistemic oversimplification that ignores a great deal of empirical data about people with intersex

\footnotetext{
${ }^{65}$ Davis (2015): 21.

${ }^{66}$ Carmack, Notini, Earp et al. (2015): 6.

${ }^{67}$ Davis (2015): 120.

${ }^{68}$ Bajszczak, Szarras-Czapnik, Oszukowska et al. (2013): 71.

${ }^{69}$ Davis (2015): 124.

${ }^{70}$ Earp, Steinfeld (2018): 9.
} 
traits. I claim that "normalizing" surgery is the expression and reinforcement of epistemic injustice, as it is a visible, physical harm made by public institutions and allowed by the law; however, the epistemic injustice exists before the surgery. Before physical violence, there is symbolic violence. It is a physical violence towards a minority group of people in the name of norms created by the dominant group. Children with intersex traits feel "the knife of the norm" ${ }^{71}$ on their bodies.

Public language is created by the powerful portion of a society. People with intersex traits are a minority, and they are different in a way that is tabooed. Their situation is discussed secretly with doctors and in narrow family circles. Their experience is hardly socially visible and has little impact on the social imagination; it is reduced to a medical issue, handed over to medical authority, and, thus, pathologized. When surgical techniques were developed, their bodies were subjected to removals, corrections and constructions (in very sensitive and intimate parts of the body) to fit the existing binary notion of two sexes. At that moment, social stigma was extended to a new kind of physical harm. However, hidden under the physical harm, the injustice is located in the social imagination.

For instance, in Polish law, the appearance of external sex organs is the key determinant of legal sex, but the law does not see the children to which the criterion cannot be applied. ${ }^{72}$ However, instead of changing the law, what is being changed are children's bodies.

Regular users of language transmit binary oversimplification and unintentionally materialize harm. Special sensitivity is needed to mitigate this harm. When we listen Fricker's advice, the only way forward is (1) to be in touch with empirical data and (2) to listen to the voice of the minority group to enrich the social interpretative resources. ${ }^{73} \mathrm{~A}$ group of intersex people started to express their experiences, ${ }^{74}$ to participate in creating language, and to build social sensitivity to the harm they have encountered. It is a slow process, as prevailing cultural traditions resist modification, even if the old norms are inconsistent with empirical data. In my view, to speed this process up, some new theories that are able to interpret "anomalies" as healthy diversities and a new multilayered and nonbinary notion of sex/gender characteristics ${ }^{75}$ are needed.

According to intersex activist Hida Viloria, "the emergence of people with nonbinary gender identities is an important step for the acceptance of all intersex people. After all, the big fear driving 'corrective' treatments is that intersex babies won't grow up to be men or women. So, if we have a whole community of people voluntarily saying that they are not men or women and living voluntarily as neither...it creates a viable community that parents can see." ${ }^{\prime 76}$ I also argue that if society understands the diversity of sex characteristics, parents may stop asking for early "normalizing" surgery, and doctors may stop recommending it.

\footnotetext{
${ }^{71}$ Butler (2004): 53.

72 Gawlik, Bielska-Brodziak (2016): 5.

${ }^{73}$ Fricker (2009): 162.

${ }^{74}$ Chase (2002); Patino (2005); Ghattas (2015); Davis (2015); Viloria (2017); Carpenter (2018) and many others.

${ }^{75}$ Ziemińska (2018): 137.

${ }^{76}$ Viloria (2017): 274.
} 
Not all people with intersex traits agree with this explanation. Australian intersex activist Morgan Carpenter presents the point of view of the majority of intersex people who have a binary gender identity. They have some diverse sex characteristics, but they are women and men in terms of legal sex assignment and felt gender identity.

From their point of view, the binary notion of two sexes is partly acceptable (if only based on self-determination instead of on sex characteristics). Carpenter writes: "The medical model seeks to make intersex bodies either female or male, while an incommensurate third-sex model seeks to classify intersex persons as neither female nor male." 77 What is currently called the "medical model" is, in fact, the simply binary model of two sexes, where there is an assumption that a person is either male or female. Intersex people have some female and some male traits, and they are in danger of being harmed by "normalizing" surgery. However, the binary model of two sexes understood as a legal classification is acceptable for the majority of intersex people. ${ }^{78}$

The third-sex model is also rejected from this point of view. According to Carpenter, as the binary model forces intersex bodies to be either female or male, the thir$\mathrm{d}$-sex model presents intersex people as neither female nor male when most of them have female or male gender identity. Under this model, they are in danger of being considered neither truly men nor truly women: "Claims that intersex is a third sex risk framing binary (female and male) sex assignment and identifications in intersex people as deceptive or transgressive." ${ }^{79}$ Carpenter claims that this model would be a new kind of epistemic injustice, ${ }^{80}$ as it would misgender those people and other the whole intersex community. According to him, both the model of two sexes and the model of three sexes are harmful. He accepts a human rights model composed of the right to the self-determination of gender identity and the right to bodily integrity. ${ }^{81}$

Some points need to be explained. I see two inconsistencies in Carpenter's view. First, he rejects the binary medical model, but at the same time, he writes that intersex people are happy with the binary model. Second, he accepts the human rights model with the principle of self-determination, but at the same time, he rejects the nonbinary category that is adopted by people who self-determine as nonbinary. If we reject the binary model on the medical level, we should also respect that it is damaging for some people on the legal level. If we accept the principle of self-determination, it should be applied to all people. This principle requires respect for nonbinary third gender identity because some people have adopted it. At the end of his paper, Carpenter acknowledges as much: "As long as legal classification is required, access to binary and neutrally termed 'non-binary' sex/gender markers should be available for any person (intersex or not) preferring such options on the basis of self-determination." 82 It is very important that Carpenter clearly presents the point of view of the majority of intersex people, but one should also consider other groups of people (especially the group of nonbinary people who overlap with transgender and intersex groups).

\footnotetext{
77 Carpenter (2018): 507.

78 Ibidem: 504.

${ }^{79}$ Ibidem: 498.

80 Ibidem: 497.

${ }^{81}$ Ibidem: 514.

${ }^{82}$ Ibidem.
} 
Carpenter discusses the idea of a simple two-sex model or a simple three-sex model, but an alternative is to start talking about sex traits instead of sexes. A nonbinary theory of sex traits that are excluded from the female/male divide is needed for a general understanding of the diversity of sex characteristics. This can be a multilayered model of sex traits and gender identities that can occur in diverse trait clusters. ${ }^{83}$ A description of the diversity is consistent with respecting gender identity. I agree that on a legal level, a particular version of the third gender category is needed: it must be "available for all individuals regardless whether they are intersex or not... at the request of the individual concerned." 84 This version of the third category can avoid additional harm to people who already suffer because of "normalizing" surgery. It can avoid an additional epistemic injustice mentioned by Carpenter ${ }^{85}$ as the reason for avoiding a nonbinary gender category.

I argue, like Hida Viloria, that including a nonbinary gender category in legal terms can contribute to breaking the simple binary model used in medical contexts. If we want schoolchildren to respect children with diverse sex traits, we need to respect gender/sex diversity in the public language and law. New theories that are able to interpret intersex traits as part of a healthy diversity can change the social binary imagination.

\section{Conclusion}

Fricker's notion of epistemic injustice, especially hermeneutical injustice, is a useful theoretical tool to explain the social situation of people with intersex traits. Until recently, such people hardly participated in the processes of creating the notion of sex and gender, and as a result, their traits have been inadequately interpreted as a kind of disorder. This epistemic dysfunction also results in physical harm from "normalizing" surgeries performed on children with intersex traits. However, these surgeries happen because injustice exists in the social imagination. It is disseminated as a binary language of two sexes, as the discrimination of people with diverse sex characteristics, and as an emergency for intersex newborns, and it culminates as physical harm approved of by the law and science done to vulnerable children. In contrast to Carpenter, I claim that to limit this harm, it is important to reject the simple binary model of two sexes.

\section{References}

Bajszczak K., Szarras-Czapnik M., Oszukowska E. et al. (2013), „Kliniczne i psychologiczne konsekwencje odroczenia gonadektomii oraz chirurgicznej korekcji obojnaczych zewnętrznych narządów płciowych do okresu dojrzałości u pacjentki z częściową niewrażliwością na androgeny," Endokrynologia Pediatryczna/Pediatric Endocrinology 2 (43): 69-80.

Boczkowski K. (1966), "Franciszek Neugebauer (1856-1914): Pioneer in the Study of Hermaphroditism," Polish Medical Science and History 9 (4): 155-157.

\footnotetext{
83 Zieminska (2018): 137.

${ }^{84}$ Ghattas (2015): 22.

85 Carpenter (2018): 497.
} 
Brussels Collaboration (2019), "The Brussels Collaboration on Bodily Integrity. Medically Unnecessary Genital Cutting and the Rights of the Child: Moving Toward Consensus," The American Journal of Bioethics 19 (10): 17-28.

Butler J. (2004), Undoing Gender, Routledge, New York and London.

Carmack A., Notini L., Earp B.D. (2016), "Should Surgery for Hypospadias be Performed Before an Age of Consent?," Journal of Sex Research 53 (8): 1047-1058.

Carpenter M. (2018), “The 'Normalisation' of Intersex Bodies and 'Othering' of Intersex Identities," [in:] The Legal Status of Intersex Persons, J. Scherpe, A. Dutta, T. Helms (eds.), Intersentia, Cambridge (UK): 445-514.

Chase Ch. (2002), "Affronting Reason," [in:] GenderQueer. Voices from Beyond the Sexual Binary, J. Nestle, C. Howell, R. Wilchins (eds.), Alyson Books, Los Angeles/New York: 204-219.

Colapinto J. (2000), As Nature Made Him: The Boy Who Was Raised as a Girl, Harper Collins, New York.

Council of Europe (2017), "Document 14404. Report by Piet De Bruyn: Promoting the Human Rights of and Eliminating Discrimination Against Intersex People," URL = http:/ / assembly.coe.int/nw/xml/XRef/Xref-DocDetails-EN.asp?FileID=24232\&lang=EN [Accessed 4.11.2017].

Creighton S., Michala L., Mushtaq I. et al. (2014), “Childhood Surgery for Ambiguous Genitalia: Glimpses of Practice Changes or More of the Same?," Psychology E Sexuality 5 (1): 34-43.

Davis G. (2015), Contesting Intersex. The Dubious Diagnosis, New York University Press, New York and London.

Diamond M., Sigmundson H.K. (1997), “Sex Reassignment at Birth: Long-Term Review and Clinical Implications," Archives of Pediatric and Adolescent Medicine 151 (3): 298-304.

Diamond M. (2009), "Human Intersexuality: Difference or Disorder?," Archives Sexual Behavior 38 (2): 172.

Darby R.J.L. (2013), “The Child's Right to an Open Future: Is the Principle Applicable to Non-Therapeutic Circumcision?," Journal of Medical Ethics 39 (7): 463-468.

Feder E. (2014), Making Sense of Intersex. Changing Ethical Perspectives in Biomedicine, Indiana University Press, Bloomington.

Earp B.D. (2019), “The Child's Right to Bodily Integrity," [in:] Ethics and the Contemporary World, D. Edmonds (ed.), Routledge, Abingdon and New York: 217-235.

Earp B.D., Steinfeld R. (2018), “Genital Autonomy and Sexual Well-Being,” Current Sexual Health Reports 10 (1): 7-17.

Fricker M. (2009), Epistemic Injustice. Power and the Ethics of Knowing, Oxford University Press, Oxford and New York.

Fricker M. (2017), "Evolving Concepts of Epistemic Injustice," [in:] The Routledge Handbook of Epistemic Injustice, I.J. Kidd, J. Medina, G. Pohlhaus Jr (eds.), Routledge, New York: 53-60.

Furtado P.S., Moraes F., Lago R. et al. (2012), “Gender Dysphoria Associated with Disorders of Sex Development," Nature Reviews Urology 9 (11): 620-627.

Gawlik A., Bielska-Brodziak A. (2016), “Dzieci bez płci. Jak polski prawodawca rozwiązuje problemy osób interseksualnych. Część pierwsza," Prawo i Medycyna 63 (18): 5-28.

Ghattas D.Ch. (2015), "Standing up for the Human Rights of Intersex People - How Can You Help? Brussels: ILGA Europe," URL = https:/ / oiieurope.org/standing-up-for-thehuman-rights-of-intersex-people-how-can-you-help/ [Accessed 27.06.2019].

Harper C. (2007), Intersex, Berg, Oxford-New York. 
Hughes I., Houk C., Ahmed S.F. et al. (2006), “Consensus Statement on Management of Intersex Disorders," Archives of Disease in Childhood 91 (7): 554-563.

Johnson E.K., Rosoklija I., Finlayson C. et al. (2017), “Attitudes Towards "Disorders of Sex Development" Nomenclature Among Affected Individuals," Journal of Pediatric Urology 13 (6): 608.e1-608.e8.

Karkazis K. (2008), Fixing Sex: Intersex, Medical Authority, and Lived Experience, Duke University Press, Durham.

Kolesinska Z., Ahmed S.F., Niedziela M. et al. (2014), “Changes Over Time in Sex Assignment for Disorders of Sex Development," Pediatrics 134 (3): e710-e715.

Koertge N. (2004), "How Might We Put Gender Politics into Science?," Philosophy of Science 71 (5): 868-879.

Kubicius K., Michałowska M. (2020), “Shaping the Body of a Child. Invasive Medical Procedures On Incompetent Patients - Some Ethical and Medical Remarks on Ashley's Case," Analiza i Egzystencja 49: 5-29.

Lee P.A., Nordenström A., Houk Ch.P. et al. (2016), “Global Disorders of Sex Development Update Since 2006: Perceptions, Approach and Care," Hormone Research in Paediatrics 85: 158-180.

Mak G. (2012), Doubting Sex. Inscriptions, Bodies and Selves in Nineteenth-Century Hermaphrodite Case Histories, Manchester University Press, Manchester and New York.

Monro S., Crocetti D., Yeadon-Lee T. et al. (2017), Intersex, Variations of Sex Characteristics, and DSD: The Need for Change, Research Report, University of Huddersfield, UK, URL = http:/ / eprints.hud.ac.uk/id/eprint/33535/ [Accessed 16.11.2017].

Patino M.J.M. (2005), "Personal Account. A Women Tried and Tested," Lancet 366: 538.

Petriczko E., Marcinkiewicz K., Słowikowska-Hilczer J. et al. (2014) „Zespół częściowej niewrażliwości na androgeny - opis przypadku," [Partial Androgen Insensitivity Syndrome - Case Report]," Endokrynologia Pediatryczna/Pediatric Endocrinology 1 (46): 61-67.

Pisarska-Krawczyk M., Jarząbek-Bielecka G., Mizgier M. et al. (2014), „Nietypowo ukształtowane narządy płciowe lub zaburzenia rozwoju płci. Aspekty medyczne i etyczne [Ambiguous Genitalia or Disorders of Sex Development. Medical and Ethical Aspects]," Current Gynecological Oncology 12 (4): 259-270.

Reis E. (2007), “Divergence or Disorder? The Politics of Naming Intersex," Perspectives in Biology and Medicine 50 (4): 535-543.

Reis E. (2009), Bodies in Doubt. An American History of Intersex, The Johns Hopkins University Press, Baltimore.

Schweizer K., Brunner F., Handford Ch. et al. (2014), “Gender Experience and Satisfaction With Gender Allocation in Adults with Diverse Intersex Conditions (Divergences of Sex Development, DSD)," Psychology \& Sexuality 5 (1): 56-82.

Szarras-Czapnik M., Lew-Starowicz Z., Zucker K. (2007), „A Psychosexual Follow-Up Study of Patients with Mixed or Partial Gonadal Dysgenesis," Journal of Pediatric $\mathcal{E}$ Adolescent Gynecology 20: 333-338.

Viloria H. (2017), Born Both. An Intersex Life, Hachette Books, New York.

Zieminska R. (2018), Niebinarne i wielowarstwowe pojęcie ptci, Wydawnictwo Naukowe PWN, Warszawa.

Zillén K., Garland J., Slokenberga S. (2017), The Rights of Children in Biomedicine: Challenges Posed by Scientific Advances and Uncertainties, The Committee on Bioethics of the Council of Europe, URL = http://uu.diva-portal.org/smash/get/diva2:1065442/ FULLTEXT01.pdf [Accessed 2.06.2020]. 